\title{
DIGITALCOMMONS
}

@WAYNESTATE-

Criticism

Volume 62

Issue 3 Renaissance Posthumanism and Its

Afterlives

Article 9

2020

\section{Faithfully Yours (and Yours and Yours)}

John S. Garrison

garrison@grinnell.edu

Follow this and additional works at: https://digitalcommons.wayne.edu/criticism

\section{Recommended Citation}

Garrison, John S. (2020) "Faithfully Yours (and Yours and Yours)," Criticism: Vol. 62 : Iss. 3 , Article 9.

Available at: https://digitalcommons.wayne.edu/criticism/vol62/iss3/9 
FAITHFULLY YOURS (AND YOURS AND YOURS)

\section{John S. Garrison}

Queer Faith: Reading Promiscuity and Race in the Secular Love Tradition by Melissa Sanchez. New York: New York University Press, 2019. 349 pp. Cloth $\$ 99.00$, paper $\$ 35.00$.
This new volume belongs to the field of study sometimes referred to as "queer theology." The range of the field is exciting in its expansiveness. At one end, we might say, studies look at the role of LGBTQI individuals in relation to religious service and worship. At another end, studies apply queer theory to wrest theological writing and social formations from the interpretations that constrict their possible meanings to often conservative ends. Embracing the latter approach, Queer Faith deploys queer theory-as well as thinking from critical race studies and from psychoanalysis-in order to deliver a study that brims with new insight that will be of use to not only those scholars studying early modern literature but also those scholars working more broadly on issues of race, religion, or sexuality.

Sanchez's introduction opens by noting how religious terms of faith have in our own contemporary culture been applied to sexualized (and often queerly sexualized) situations. Citing examples in popular music, ranging from George Michael's "Faith" to Lady Gaga's "Judas," the author posits that "these lyrics cite a tradition formalized by Dante and the troubadours, diffused into European discourse by Francesco Petrarch and his Renaissance imitators [in which] true love, as distinct from lust and infatuation, resembles religious faith in 
structure" (1). Sanchez acknowledges this tradition in order to throw into relief another strand of thought that her volume will trace through the same genealogy of writers. From the onset, the book helps us see that religious language and logical formulations have also been used by writers to justify adultery, divorce, and the pursuit of multiple partners, as well as a variety of erotic affiliations outside the terms of conjugal relations. In their 1995 essay that early on helped define the aims of queer study, Lauren Berlant and Michael Warner pointed to an array of narratival elements that could be made legible through the application of the field's tools: "cultures of reception," "the costs of closure," "the pleasure of unruly subplots," "voicing strategies," and "identification and other readerly relations to texts and discourse."' Sanchez's study elegantly proves that such an approach still has power today as her examination of early modern texts grants insight into the nature of issues at the heart of the concerns of queer theory. These include non-heteronormative forms of erotic relations, the construction and shattering of the self, the role of erotic relationships in personal askesis, and viable yet against-thegrain readings of canonical texts. By applying queer theory in the best of ways, Queer Faith reveals the surprising complexities and often counterintuitive interoperations of religious discourse and lyric poetry in the early modern period.

The keywords in Queer Faith's subtitle-_promiscuity," "race," and "secular"-signal the productive complexity of Sanchez's wonderful new study of familiar and unfamiliar verse. The book evinces how early modern lyric offers a powerful case study for the racial dimensions of monogamy, where excess in libidinous desire has long been aligned with individuals coded as nonwhite (e.g., the "black lady" of Shakespeare's sonnets). And while such color-related descriptors of individuals may not always refer to a person of color, they still participate in traditions that have associated promiscuous or sinful behavior with blackness. In opposition to such associations, we can find other figures (e.g., the "fair youth" of Shakespeare's sonnets) whose virtue seems to be aligned with whiteness. Although such binaries might hold true in broad brushstrokes, Sanchez also shows their instability. She builds upon important work by scholars such as Geraldine Heng, Ania Loomba, and Ayanna Thompson, as she is careful to note that in the early modern period (as in today's culture), race is "a dynamic and shifting social and cultural construct," and that we must be careful to study race in the early modern period without "endow[ing] 
modern racialization and racism with a precision, intelligibility, and stability that they do not in reality have" (13). As Peter Erickson and Kim F. Hall have recently pointed out, studying race in the early modern period "emphatically does not mean using the same definition of race across the entire historical spectrum"; instead, "the challenge is to trace the variations as the idea's significance changes over time, as well as to consider how our own historical moment shapes our questions." ${ }^{2}$ Sanchez deftly navigates the complexity of this terrain by simultaneously revealing the racial valences in literary figurations used in early debates around what constitutes virtue and vice while also underscoring the instability of these categories.

Certainly, early modern literature has long been an object of study for scholars of queer theory. However, a wider examination of that literature (beyond, say, Shakespeare), especially religious writing and the secular writing that engages theological debates, has been slow to come under the scrutiny of queer studies scholars. By addressing this lacuna, Queer Faith connects to the recent edited collections, Queer Milton (2018) and Sexual Disorientations (2017), which similarly show the effectiveness of queer theory to generate new readings of canonical authors and seemingly orthodox points of view. ${ }^{3}$ Taking a longer view, Sanchez's study closely dovetails with the work of Richard Rambuss, whose Closet Devotions (1998) looked at the lyric of Donne, Herbert, Crashaw, and others. In that groundbreaking study, Rambuss traced the queer erotics inherent in so much early modern devotional practice and writing that had been overlooked by scholars seeking to chart the queer early modern. Closet Devotions emphasized how "as much as religious devotion-even the sacred itself-is a social practice, its relation to the normal order of things is seldom strictly circumscribed to the orthodox." "Queer Faith follows along in this legacy but breaks new ground by looking at a wider array of human sexual relations and by integrating race into the discussion.

In terms of the overall project, the book's aims are marked by rigor in method and by audacity in argument. As a starting point, Sanchez examines the theology of the divided will found in the Pauline epistles, which she treats as "a neglected resource for queer theorizations of desire and subjectivity" (2). This thinking, in turn, allows her to trace the far-reaching influence of the Pauline epistles, in the thinking of Saint Augustine, John Calvin, and Martin Luther, and as well in the verse of John Donne, John Milton, Francesco Petrarch, William Shakespeare, Philip Sidney, Edmund Spenser, and Mary Wroth. Queer Faith shows 
us how these writers all engage Pauline thinking yet extrapolate it to diverse ends that by no means support a singular valorization of heteronormativity, conjugality, and monogamy.

The book is divided into five chapters, each exploring different dimensions of the argument and productively complicating the book's claims at each new turn. The first chapter grounds the book in the Pauline Epistles. It then traces a genealogy of thought that links the tropic language of religious commitment to that of romantic fidelity in writing from Paul to Augustine to Petrarch. Chapter 2, "The Color of Monogamy," pivots to show us explicitly how the line of inquiry will interrogate issues related to gender and race. The chapter identifies the racial and gendered valences of distinctions between the "fair" young man and the "black" mistress in Shakespeare's sonnets only to undermine the opposition between these figures in terms of their connection to purity, agency, and fidelity. The third chapter looks at Protestant thinking regarding marriage. The chapter elegantly ties thinking from Calvin and Luther not only to Shakespeare's Sonnets but also to Spenser's Amoretti and Epithalamion. The chapter opens with neither the early modern theologians nor the poets, however. The discussion commences with the 2015 U.S. Supreme Court decision in Obergefell $v$. Hodges that legalized gay marriage. The decision, as Sanchez notes, did important work to extend access to marital unions for those who desired them, but it also threatened to delegitimize further those who wish to remain outside of relationships defined by monogamy, conjugality, or the model of dyadic relations.

Turning our attention to themes of divorce and infidelity, chapter 4 opens with an incisive reading of the New Testament and Reformation theology. This lays the groundwork for interpretations of Milton's divorce pamphlets as well as sonnet sequences by Sidney and Wroth. We see that these writers justify adultery, divorce, or overlapping erotic relations through an interpretation of Pauline ideas about love versus duty and letter versus spirit that "infuses faith itself with a salutary faithlessness" (158). The fifth chapter then examines Donne's poetry, specifically those works where the speaker is an unfaithful lover. Here, Sanchez finds that the poet "is at his most Petrarchan, and his most religious, when he confesses to a future of promiscuity" (200). This notion points to a crucial thread that we find throughout the volume: failure to live up to divine ideals and the subsequent need for forgiveness make promiscuity an apt expression of religious devotional practice.

The book's coda widens the lens of the argument, making larger 
claims about the academic work of scholars and about periodization. Sanchez looks at how academia is driven by the same love and same "imperative to commit" that we find in the lyric examined throughout the volume (245). The same categories of selflessness, attachment, and authenticity, as well as the emphasis on good work, that characterize assessments of true love also characterize the discourse with which scholars describe their dedication to topics, theoretical frameworks, and periods that they study. Queer Faith all along has asked its reader to think about the purchase of fictions of the past upon truisms of the present. It seems only apt that the author would ask her readers to meditate on their own subject positions in relation to their own work as they close their consideration of this vibrant study.

\section{NOTES}

1. Lauren Berlant and Michael Warner, "What Does Queer Theory Teach Us About X?”, PMLA 110 (1995): 110.

2. Peter Erickson and Kim H. Hall, “'A New Scholarly Song': Rereading Early Modern Race," Shakespeare Quarterly 67, no. 1 (2016): 7.

3. Queer Milton, ed. David L. Orvis (London: Palgrave Macmillan, 2018); and Sexual Disorientations: Queer Temporalities, Affects, Theologies, ed. Kent L. Brintnall, Joseph A. Marchal, and Stephen D. Moore (New York: Fordham University Press, 2017).

4. Richard Rambuss, Closet Devotions (Durham, NC: Duke University Press, 1998), 9. 